\title{
The Generalized Minsky Moment
}

\author{
James K. Galbraith \\ LBJ School of Public Affairs \\ University of Texas at Austin \\ Austin, Texas \\ galbraith@mail.utexas.edu \\ Daniel Munevar Sastre \\ LBJ School of Public Affairs \\ University of Texas at Austin \\ Austin, Texas \\ danielmunevar@mail.utexas.edu
}

February 2, 2009

University of Texas Inequality Project

UTIP Working Paper No. 56

\begin{abstract}
:
The cornerstone of Hyman Minsky's work is the concept of systemic instability. His work showed how systemic dynamics inherent to capitalism bread systemic fragility and crisis, as stability spurs risky behavior. Like Minsky himself succinctly articulated, "stability is destabilizing" (Minsky 1985). Moreover, this key notion is not only based on a clear and detailed analysis of modern financial capitalism, but is also essentially rooted on human psychology and behavior. As such, it is astonishing how little has been done to expand Minsky's basic conceptual framework to other fields of study of social science. This paper represents an effort to fill this vacuum, as it attempts to expand Minsky's theory of financial fragility to the realm of international relations. The objective of this project is to analyze the cycles of international relations in the light of a modified version of Minsky's famous analysis of hedge, speculative and Ponzi finance.
\end{abstract}




\section{Introduction}

Whether the current financial crisis is a bona fide "Minsky moment" is a matter for debate. Davidson (2008) firmly disputes that subprime mortgages constitute 'Ponzi finance" in the technical sense that Hyman Minsky intended. We don't disagree. Yet the fact that current events have again raised the profile of Minsky's contribution is still a good thing, and we propose here to take advantage of it. In this paper, we suggest that Minsky's taxonomy of financial behavior can be generalized far beyond its original sphere of application. Thus we offer a "generalized Minsky moment".

The concept of systemic instability is the cornerstone of Hyman Minsky's work. Minsky argued that system dynamics inherent to capitalism breed fragility and crisis, as stability spurs risky behavior, and risky behavior leads to crisis. As he put it, most succinctly: "stability is destabilizing" (Minsky 1985).

This key notion is based on a clear and detailed analysis of modern financial capitalism, but it is also rooted on human psychology and behavior. There is nothing that restricts the application of Minsky's insight to the pecuniary realm. It is therefore astonishing how little has been done to extend the basic conceptual framework to other areas of social science.

This paper is a first effort: we attempt here to take Minsky's theory of financial fragility into the realm of international relations. Our modest objective is to sketch an analytical framework that may help describe the economical, political and military interactions of nation states, in the light of Minsky's famous analytical distinction between hedge, speculative and Ponzi finance.

The paper is presented in two sections. Section 1 outlines the theory. Section 2 presents a brief overview of modern history, using the terminology developed in Section 1. The section also show the connection between cycles of international relations and the evolution of the international monetary system. Thus it will develop that in this sphere, 
deterioration of the risk environment in politico-military terms usually has a counterpart in pecuniary relations after all.

\section{A Minskyan Approach to International Relations Theory}

In Minsky's financial analysis, the unit of observation - the behavioral entity - is the firm. In our Minskyan theory of international relations, the unit of analysis is the nationstate. In this respect, we follow the conventional rational-actor paradigm of the standard realist international relations theory. However, we are not wedded to that interpretation. In a model of bureaucracy or politics, risky behavior for the conglomerate entity can emerge from stable environments in consequence of the actions of individual players, who become emboldened to test the limits traditionally placed on their behavior by convention, ethics, regulation or law. This is similar to the way in which firms can be endangered by risky behavior emanating from the CEO, from the ranks of management, or through a failure of labor-management relations.

Just as all firms do not possess the same relationship to the market, nation states do not enjoy symmetric relations within the global system. Rather, international relations exhibit an intricate and dynamic hierarchical structure. The central position is occupied by a hegemon, the preeminent power within a given sphere of influence. A second tier is composed of allies: countries that benefit from the established system but do not control it, whose economic and technological development put them in a position from which they may eventually move into control, should the hegemon falter. A third tier is composed of peripheral countries - the exploited - which provide commodities, labor, human capital and export markets to the hegemonic powers of the system. In former times peripheral regions were usually colonies. Today they may still be governed by agents of the hegemonic powers, directly or indirectly; their sovereignty and access to credit remain limited and their currencies, typically, are soft.

There may, of course, be several hegemonic systems in the world at any given time. 
The degree of influence that each nation-state has within the international system thus varies according to its status. As in the case of market power -- which determines the ability of firms to set mark ups and earn profits -- the status of a nation-state determines the share of benefits that it receives from the hegemonic system of which it forms a part. In international relations as in economics, market power and (analogously) status only determine the distribution of profits, not total income or system welfare. The latter depends on macroeconomic conditions (Minsky 1986: 143), a product of collective endeavor.

We will focus here on the interaction of the countries belonging to the first two tiers of the system, that is the hegemon and its allies. Within each system, each member faces the eternal trade-off between self-interest and collective interest, between actions aimed to increase its power at others' expense and actions to improve the collective welfare. Total welfare depends on progressive development, which requires peace, good governance and good order, at least between the hegemon and its allies. Violence toward the periphery or toward other hegemonic systems is a separate matter, since both the hegemon and its allies can benefit from it under certain material conditions. But it is risky.

Firms in a modern financial economy gain market power initially by production of something for sale, on an exclusive or semi-exclusive basis. Firms go on to exercise power, however, not only through price mark ups, but also through portfolio transactions - through borrowing and lending in the capital markets. In this way they can consolidate power, by acquiring and eliminating rivals. But generally a firm cannot obtain finance, and therefore its ability to produce is limited, unless it has market power in the first place (Papadimitriou and Wray 1999).

Similar exclusive or semi-exclusive control over key production processes typifies the political hegemon and its allies in the global system, and this is necessarily connected to a privileged financial position. A country cannot develop effective military capability unless it holds significant technical advantages, and it cannot finance the development 
and maintenance of state power unless those advantages are recognized by financial markets. Hence the eternal importance of bankers to princes.

For this reason, even a hegemon faces certain limits on its power. It depends, for the continuity of its status, on the forbearance of its allies and, to a degree, also that of the peripheral countries within its sphere. It must borrow from the former, in order to sustain its technical and military advantages over them. As for the latter, their resistance and resentment cannot be so great, as to force the hegemon into an exhausting struggle to maintain its position.

In the international system, economic and technological development play the role of cash-flow- generating activities: they are the ongoing bread-and-butter of a power position. Military power and the financial arrangements required to support it, on the other hand, play the role of portfolio transactions: they are devices to project power beyond what can be justified by economic and technical supremacy alone. The game of maximizing status can be played through either channel, and great hegemons invariably play it through a combination of both.

For any firm, there will always be uncertainty about the match between cash-flow generating activities and portfolio transactions. The former are based on assumptions about future market conditions, the latter are given by contract and therefore known, at least to within the contingencies specified in the contract (Minsky 1986:205). Thus the first question facing the firm is whether the underlying basis of its market power -a superior product at a price not challenged by effective competition- will continue to generate profits sufficient to cover financial commitments.

In the case of the nation-state, the costs of peacetime military power are in the public budget and therefore known, while in most of modern history the financial obligations of the state are also disciplined by knowledge of - or at least a convinced belief in - the limitations imposed by financial markets. On the other hand, technological and therefore actual military superiority, in the event of war, are always uncertain, because they 
always depend on the prospects of future competition. They depend, that is, on a matchup in the marketplace or on the battlefront that has not yet occurred, that may never occur, and whose outcome if it does occur cannot be entirely predicted. Great powers are riven by anxiety about their actual and potential rivals, of whom their knowledge of conduct and performance is "based on conjectures and therefore uncertain by nature" (Minsky 1986:205).

Like firms in a market economy, countries seeking to project and defend their power must innovate, experiment and improvise. The competition is always in mind; "objects in the mirror" often appear closer than they are. Like firms, countries "operate on the basis of trial and error; if a behavior is rewarded, it will be repeated. Thus, stable periods naturally lead to optimism, to booms and to increasing fragility." (Papadimitrou and Wray 1999).

For Minsky, financial instability is linked to the relative importance of the different sources of revenue. Three basic profiles describe the reliance of firms on the different types of income: the hedge, speculative and Ponzi profiles. Firms engaging in hedge finance rely mainly on income cash flow to fulfill their obligations, whereas speculative and Ponzi schemes rely increasingly on portfolio transactions. The former face ordinary market uncertainties; any crisis they face is of ordinary competitive performance and market conditions, given the financial commitments.

This is not so for those engaging in speculative finance. Firms in a speculative position have taken on financial obligations for which expected cash flow is not expected to be fully sufficient. They must therefore not only maintain cash flow but also refinance their positions periodically. A speculative position may be refinanced if market conditions do not change, but it is vulnerable to unforeseen changes. If a firm in such a position cannot successfully refinance, the speculative position may simply collapse. But it also may become a Ponzi position, inherently unsustainable and prone to collapse, once its nature is recognized by the world. 
The extension of these ideas to international relations is straightforward. Countries contesting for economic and technological advantage in a stable world environment are the analogs of hedge players: they are relying on future cash flow to assure their prosperity and progress, and to meet their commitments. Their financial capacity reflects an acknowledgment of economic and technological power, and they are financed because that power is expected to be sustained. The uncertainties they face are those of their own material capacities and competitive conditions.

A speculative profile would occur when a hegemonic power uses its power - particularly the threat of military action - to project influence in a way that is hostile or challenging toward other powers, or when an allied country decides to challenge the hegemon within its own system. The problem is that the position provokes the reaction of another strong player, and therefore comes under challenge. The speculative position must therefore be "refinanced" periodically, under conditions whose character cannot be known in advance. The position may be tenable, or it may not be. If the position is untenable, the speculative player has two options: he can fold his hand, or he can double down and hope for the best.

As in finance, the transition from a speculative to a Ponzi profile is not fully under a country's control. It depends on whether the speculative position can be refinancedwhether a provocative confrontation is resolved without escalation in the form of an arms race or outbreak of violence, either of which may have dire financial implications, and whether those implications can be handled by the hegemon's bankers. Once open conflict starts, it generally requires more economic resources than were provided for in the advance planning, and a process of accelerated depletion gets underway. If what was initially considered as a limited engagement transforms into a military quagmire or explodes into total war, a vicious cycle takes place that often ends with the collapse of the regime.

It is worthwhile to specify how national positions are affected by the evolution of the system and vice versa. A country in a hedge position maintains its status mainly through 
the development of economical and political influence. It relies on the mechanisms of collective security; if it is an ally it does not challenge the leadership of the hegemon and if it is the hegemon itself, it does not overreach and provoke revolt or passive resistance amongst its allies. Again, abuse of the periphery is routine for both parties, but the periphery is, as a rule, so weak that it cannot effectively fight back, consequently the benefits of such abuse routinely exceed the costs.

The shift from a hedge to a speculative profile is typically a product of the success of this system. A hegemon at the peak of a well-functioning alliance and with a dependent periphery well under control, may decide to challenge other hegemonic powers. Indeed, in the extreme case of a globally preeminent hegemon, the very existence of spheres of influence outside direct control may seem intolerable. Needless to say, success against one rival hegemonic system is likely to breed extreme confidence that others are equally open to attack.

An allied state, weary of lending to its own hegemon, may come to feel that the security provided by membership in the hegemonic system is not worth the economic cost of the tribute required to sustain it. While direct conflict between a hegemon and its allied powers is rare, this challenge can take a more subtle form. Specifically, it can consist of denying easy credit, and therefore undermining the hegemon's chances of prevailing in a contest with third parties.

Once in the speculative position, countries are exposed not only to commercial, technological, economic and political risks - which is also true of hedge countries - but they also become vulnerable on the military and financial fronts. Bad things can then happen, and sometimes they do. When speculative positions must be financed, the terms on which they are refinanced may be unsustainable, in the sense of being incompatible with national success over time. But it is still better to refinance, and defer the day of reckoning, than to admit defeat. Thus, as with a firm, once a speculative position has been taken, the shift to a Ponzi position is largely outside national control. When it happens, it renders the national position and that of the system as a 
whole as critically unstable (Minsky 1986:208-209); collapse is inevitable in due course.

Consequently, for countries as for firms, the movement toward the generalized Minsky moment comes in two phases. "The shift toward speculative positions, or fragility, occurs intentionally (and more-or-less inevitably because of the way in which expectations are affected by success), while the shift from speculative toward a Ponzi scheme is mainly unintentional"(Papadimitrou and Wray 1999).

There is an additional significant difference in the way speculative and Ponzi actors behave, as noted by Kregel (2004). The main objective of a speculative actor in international relations is to secure or expand economic and political advantages. The speculative actor relies in certain periods on military threat, but avoids open confrontation. When the situation transitions to the Ponzi phase, there is an inversion between means and objectives. Economic and political influence cease to matter, except as they can help to sustain the active projection of military power and the financial backing it requires. The scheme is sustainable only so long as military and financial power can keep adding to economic and political assets. When it can no longer do this, the system crashes. This is because both the economy and the political system, already under severe stress in various ways, are unable to cope with the material, human and financial losses associated with the active projection of power against equally active opposition.

Once a Ponzi position exists, no shock is needed generate a crisis. As Tymoigne (2006) explains, "the immediate cause of a crisis does not matter. The forces at work that led to the crisis started to operate a long time before the factors triggering the occurrence of the crisis".

\section{Minsky and Modern History}

So: stability is destabilizing. If this were all there were to it, one might expect, as a logical outcome, a constant stream of wars between hegemonic powers. Similarly in the 
case of the financial system, one might expect a constant and recurring condition of crisis. But as a matter of history neither is the case. Confrontation, crisis and collapse have all happened, with bruising frequency, in the historical record. But hedge positions have also held for a long time, most notably in living memory.

From the end of the Napoleonic Wars until the outbreak of World War I Europe enjoyed comparative peace, interrupted more frequently by revolution than by war. Wars were of course continuous throughout this period, but in remote regions: across Africa, in India, in China, in the Crimea, between Japan and Russia, and inside the United States. Wars on European soil were rare, the notable exception being the quick Prussian victory over France in 1870 . Why?

We believe the broad answer lies in the development of the national army, following the French Revolution and the consolidation of Germany (and Italy) into nation-states. In the context of the industrial revolution, the rise of the railroad, and the possibility of fullscale mobilizations, the national army was a new and quite terrifying development. It greatly raised the uncertainty associated with the prospect of military conflict close to home, and so induced hedging behavior: competition focused on obtaining maximum economic and demographic supremacy, alongside the largest possible dependent empire. Bismarck, in particular, was a consummate hedge player, never going outside the power structures justified by Germany's rising industrial capacity.

Three elements were key in the processes of 19th century colonization. The first was the overall supremacy of the UK, especially on the high seas, which promoted caution among those powers who might consider themselves her rivals. (Block 1977: 12) The second element was the use of military means to establish free trade: "the free movement of goods, people and money that developed under British hegemony between 1870 and 1913, was made possible, in large part, by military might, rather than market forces" (Chang 2008: 24). The third was the development of advanced technologies and weaponry, giving European countries a decisive advantage over peripheral regions, which made imperial expansion a cheap enterprise (McNeill 1982: 258). Empires developed but 
those of France, Germany and Austria-Hungary were distinctly second- class.

By the early twentieth century, the project of empire-building had reached geographic limits; while for each major European power the successes of the late 19th century bred a surpassing confidence in their military capacities. What remained was to tread on each other's toes, while engaging in a broad arms race. Hedge behavior became speculative, and crises between competing empires started to erupt, revealing among other things the weakness of the Russian empire (1905) and (at Tangier) the diplomatic isolation of the Germans. The Kaiser was emboldened by the first and enraged by the second; both moved him along the path of further speculative bets. It did not take much, in August 1914, for the speculative position to be transformed into a Ponzi profile by the assassination of Archduke Ferdinand at Sarajevo, the subsequent mobilizations and the outbreak of war. Once war started, there was nothing to do except double down, repeatedly, until by 1918 all the major European powers were bled dry and exhausted.

In the inter-war period the cycle repeated, in part because efforts to restore a stable hedge position were crippled from the beginning by the Carthaginian peace imposed at Versailles and by the defective design of the League of Nations. With the Great Depression, any prospect for a collaborative path toward economic development collapsed, and Germany launched on its well- known strategy of speculative confrontation with Britain and France.

The historian Adam Tooze (2007) has rewritten the economic history of the Second World War, to emphasize that German strategy, including the genocide, was substantially driven by a lust for land; without lebensraum and the agricultural terrain it would bring into German hands the Nazi leadership believed that Germany would be permanently reduced to the status of a second-rate power. For Germany, therefore, the hedge behavior compatible with sustained peace was never an option. Hitler chose to gamble, and initially, in Austria, Czechoslovakia, Poland, Belgium, Holland and France, his speculations paid off. In each case aggression provided a reward vastly greater than its cost. This led, in classic Minsky fashion, to overconfidence and willingness to increase 
the bet, until in May of 1941 Germany challenged the Soviet Union.

From that point forward, Germany's industrial and military capacities were limited quite severely by its finances. To pay for critical supplies from neutrals such as Sweden and Switzerland, equally critical materials including coal and steel had to be exported. Populations that had been over-run had to be looted, starved, even murdered: a costly and inefficient process. Petroleum could not be bought, and had to be seized instead. Labor could not be paid, so slaves were imported and worked to death. Tooze makes clear, in particular, that (contrary to the conclusions of the United States Strategic Bombing Survey), the "armaments miracle" which brought German war production to a peak at the end of 1944 would have ended quite soon. Japan's financial situation was, if anything, even more extreme, and Japanese policies in Manchuria and in occupied regions of the Pacific basin reflected this. Both systems were unsustainable, and if the war had gone on long enough both countries would have collapsed even if they had not been overrun.

In the cases of Britain and the Soviet Union, the situation was quite different as these countries were bound to each other and to the United States and the larger world by a functioning financial network. This permitted recognition of the Ponzi character of the British commitment, in particular, to be deferred until after the war was over. Britain borrowed heavily from the United States but also from its Empire, including India; these debts could be settled in part by granting independence after the war. But the result was in many ways effectively the same in the aftermath: Britain no less than Germany was to be reduced to second-tier status by the consequences - in her case financial rather than material - of World War II. The Soviet Union would escape this fate only by hanging on to an empire won on the ground. And only the United States, as the surviving hegemon of the world system, would have the luxury of writing new rules for the period to follow.

They were, by and large, enlightened rules. The end result of World War II was the construction of a world financial and political system that enforced hedging behavior on the major players for about twenty years. Each aspect of the system: the UN Security 
Council, NATO, the International Monetary Fund, the World Bank and each major program, from the Marshall Plan through the development of the European economic community, worked on the basis of mutual obligation and restraint. This was buttressed, in relations between the great powers, by the doctrines of deterrence and containment and by the deterrent power of the nuclear bomb. This period thus made possible the larger accomplishment of rapid economic recovery and sustained de velopment - albeit based, as we now realize, on accelerated depletion of the world's natural resources and its environmental capacity to absorb the waste products of industrialization.

For Minsky, the apparent stability of the post-war economy was founded on the combined impact of strong regulation enforced by strong institutions, and the policies of Big Banks and Big Government effectively implemented from the onset of the New Deal. This stabilizing framework precluded excessive risk-taking and blocked the movement of financial players from hedge to speculative positions. Those movements that did occur could be managed; if the overall system was stable, the instability of small elements within it could be largely offset when difficulties arose. Likewise the international political system.

Yet as Minsky's thesis would predict, it did not last. The Cold War fostered hedging behavior by the hegemonic powers and their allies, but it also channeled outbreaks of actual violence away from the center and into the peripheral countries. The periphery was therefore wracked by violence. And some of that violence placed the two world systems in conflict, initiating the step- up process from hedge to speculative conflict.

The United States, in response to revolutionary initiatives--a form of what it perceived to be speculative behavior from the communist camp--moved to a speculative position of its own in Vietnam in the mid-1960s. Ultimately the U.S. lost militarily, but this came at a moment after détente had been reached with China, and the loss was therefore not of strategic importance. What bothered U.S. hegemony more in this period was the unsupportive financial behavior of its allies. Well before the defeat, the stalemate in Vietnam led to an unraveling of the favored position of the U.S. at the heart of the 
Bretton Woods system - forcing the U.S. off the gold- exchange standard in 1971 and moving to a system of flexible exchange rates in 1973. It has often been argued that a more restrictive fiscal policy in the late 1960s would have preserved the old system, but Eisner (1968) persuasively refutes this view. Given the unwillingness of the world to write blank checks, the only thing that could have saved the economy, as Eisner wrote, was not to get involved in the war in the first place.

The United States ultimately recovered from its Vietnam-engendered financial troubles. It did so by launching another major aggression against the periphery, this time in the form of the debt crisis precipitated by tight monetary policies in the early 1980s. The dollar was restored as the reserve currency for the entire world, and the basis laid for American economic expansion to resume into the 1990s. Unlike military adventurism, financial aggression paid.

Meanwhile, much of the world continued to feel a need to finance the military superiority of the United States, and success emboldened, as it always does. The economic decline of the Soviet empire made challenges to that empire's position, as in Afghanistan or by Star Wars, highly effective in relation to their cost. And China, in addition to Japan, emerged as a power willing to support the U.S. financial position, in return for secure access to U.S. markets and also secure access to the raw materials and food of the Western hemisphere and the energy of the Middle East.

The peaceful end of the Cold War was expected by many to augur "the end of history" (Fukuyama 2002). But the Minskyan logic dictated a different result. The end of the Cold War brought the prevailing structures of deterrence at least partially to an end, while fostering a sense of triumphalism in the surviving hegemon, the United States. It therefore encouraged elements within the U.S. to enter once again what could be identified as the speculative face of the cycle. As Madeleine Albright famously remarked to Colin Powell, "What's the point of having this superb military you're always talking about, if we can't use it?" 
With the first Gulf War, the United States "kicked the Vietnam Syndrome for good," greatly encouraging the architects of military power to brave its actual use. Through the 1990s, even though the U.S. remained cautious, largely multilateral, and restrained in the ways military power was deployed, the ultimate successes of interventions in Bosnia and Kosovo reinforced the view that U.S. military power could not be effectively challenged. This increasing confidence would lead to the taking of new speculative positions in the period immediately following September 11,2001. A seemingly easy victory in Afghanistan would then increase the boldness with which policymakers were willing to approach other problems and other goals and objectives. But then came Iraq.

The Iraq war confronts American leadership, for the first time since Vietnam, with a speculative bet gone bad. The idea was that the war would be brief, successful, and that it would cost practically nothing. Had that been the case, then of course the architects of the war would have gone on to bigger things. They miscalculated. Why?

The principal reason now appears clearly. Iraq was not, as the war planners supposed, an isolated peripheral country like any other. It was, rather, a country well within the geopolitical reach of a neighboring hegemon - a country outside the U.S. sphere of control - that was, because of its minor place on the world stage, not clearly recognized as such at the time. This is Iran. Iran has proved very capable of projecting power into the Iraqi vacuum. American leaders thought they were knocking over a minor adversary, and ended up empowering a much more significant one.

And so after five years American leaders find themselves with no path to victory, with declining credit and no plausible way, consistent with their own goals and reputations, to engineer a return to the hedge system of mutual stabilization. To return to a hedge position is possible, but it would require leaving Iran in charge in Iraq. If this does not happen, the inexorable Minsky logic suggests that at some point the only way to refinance the power debts of the Iraqi debacle will be to incur new ones, for instance by taking on the rival hegemon directly. 
Unlike Vietnam, the United States military cannot be defeated in Iraq. But that is not the issue. Rather, the American position depends on a willingness, by the world, to finance it. And that willingness depends, in turn, on three conditions. First, it depends on a continuing conviction by some countries-our ostensible allies- that the costs of failing to support the American global position outweigh the costs of maintaining that support. Second, it depends on a belief in other countries - in the periphery and among rival powers - that American military power cannot be successfully defied. Iraq has already gravely undermined both propositions. An attack on Iran would, without doubt, undermine them even more - particularly if it endangers the access of Europe, China and Japan to Middle Eastern oil.

The third condition is that the financial system of the United States remain second to none as a safe-haven for the maintenance of liquidity and investment value. The subprime crisis, the freeze-up of interbank borrowing, and the generally skittish and unreassuring behavior of the U.S. financial authorities all work to undermine this third condition.

The situation thus poses the question: at what point does a speculative bet gone bad turn into a Ponzi profile? That question remains unresolved, just as the value of the international dollar hangs in the balance. It is an uncomfortable position, particularly when one recognizes that the potential for doubling down, for raising the speculative bet, remains very much alive. 


\section{References}

Andreassen, P. 1993. "The Psychology of Risk: A Brief Primer" The Jerome Levy Economics Institute of Bard College, Working Paper 87.

Block, F. 1977. "The Origins of International Economic Disorder: A Study of United States International Monetary Policy from World War II to the Present". London: University of California Press.

Chang, H. 2008. "Bad Samaritans: The Myth of Free Trade and the Secret History of Capitalism". New York: Bloomsbury Press.

Davidson, P. 2008, "Is the Current Distress Caused by the Sub-Prime Mortgage Crisis a Minsky Moment? Or is it the Result of Attempting to Securitize Illiquid Non Commercial Mortgage Loans" Mimeo.

Eisner, 1968. "War and Taxes: The Role of the Economist in Politics," Bulletin of the Atomic Scientists, June. pp. 13-18.

Fukuyama, F. 2002. "The end of history and the last man". New York: Perennial.

Kregel, J. 2004. "External Financing for Development and International Financial Stability."United Nations Conference on Trade and Development, G-24 Discussion Paper Series, No. 32.

McNeill, W. 1982. "The Pursuit of Power: technology, armed forces and society, since A.D 1000”. Chicago: University of Chicago Press.

Minsky, H.P. 1985 "The Legacy of Keynes." The Journal of Economic Education, Vol. 16, No. 1. 1986. Stabilizing an Unstable Economy. New Haven: Yale University Press.

Papadimitriou, D. B. and L. R. Wray. 1999. "Minsky's Analysis of Financial Capitalism." The Jerome Levy Economics Institute of Bard College, Working Paper 275.

Tooze, Adam, 2007. Wages of Destruction: the Making and Breaking of the Nazi Economy, New York: Viking.

Tymoigne, E. 2006. "The Minskyan System, Part I. Properties of the Minskyan Analysis and How to Theorize and Model a Monetary Production Economy." The Jerome Levy Economics Institute of Bard College, Working Paper 452. 